\title{
Adsorption of Hexavalent Chromium using Tamarind Fruit Shell
}

\author{
Apsara V H \\ Student \\ M.sc Chemistry \\ Snm College Maliankara
}

\begin{abstract}
To investigate the Biosorption of chromium(VI) Ion using crude tamarind fruit shell (CTFS) and $\mathrm{HCl}$ treated tamarind fruit shells (H-TS) from aqueous solution at room temperature..To compare the extent of biosorptionbetween untreated and treated forms of the tamarind shells..To evaluate the influence of different experimental parameters such as $\mathrm{pH}$, effect of initial metal ion concentration and effect of dosage of adsorbent on biosorption.
\end{abstract}

\section{INTRODUCTION}

Heavy metals are naturally occurring elements that have a high atomic weight and a density at least five times greater than that of water. Their multiple industrial, domestic, agricultural, medical, and technological applications have led to their wide distribution in the environment, raising concerns over their potential effects on human health and the environment. Their toxicity depends on several factors including the dose, route of exposure, and chemical species, as well as the age, gender, genetics, and nutritional status of exposed individuals. Because of their high degree of toxicity, arsenic, cadmium, chromium, lead, and mercury rank among the priority metals that are of public health significance. These metallic elements are considered systemic toxicants that are known to induce multiple organ damage, even at lower levels of exposure. They are also classified as human carcinogens .Due to their persistence in nature it is inevitable to become essential to remove them from waste waters. Conventional techniques have limitations and often are neither effective nor economical especially for the removal of heavy metals at low concentrations. New separation methods are effective and environmentally acceptable at affordable cost.

An alternative method for the removal of heavy metals is considered based on the biological methods of metal removal and recovery. Microorganisms play a significant role in bioremediation of heavy metal contaminated soil and wastewater. The ability of microorganisms to remove heavy metals from aqueous solutions has been known for some decades. The removal of the metals occur actively only with living cells and or passively at the surface of dead cells .This is known as Biosorption.(2)

Biosorption is a fast and reversible reaction of heavy metals with micro organisms or biomass. In this study, heavy metal resistant fungi and bacteria were isolated from the soil samples of an electroplating industry, and the bioaccumulations of $\mathrm{Cr}(\mathrm{VI})$ by these isolates were characterized to evaluate their applicability for heavy metal removal from industrial wastewaters. The optimum $\mathrm{pH}$ and temperature conditions for both the growth and heavy metal removal were determined for each isolate. The optimal $\mathrm{pH}$ for fungal isolates was lower (5-5.2) than that for bacterial isolates. The observed effects of $\mathrm{pH}$ was attributable mainly to organism-specific physiology because in all the tested cases the cellular growth positively correlated with heavy metal removal.

The byproducts obtained from biomaterial production are cheap source of biosorbents. Therefore biosorption is potential cost effective way of removing heavy metals from industrial wastewater. The process is effective even if the concentration is as low as $200 \mathrm{~g} / \mathrm{ml}$.

Several approaches have been studied and developed for the effective removal of heavy metals using biosorbent like microbial biomass and other agricultural by products soya been hulls, walnuts hulls, cotton seed hulls and corn cobs. It has also been observed that these biosorbents need further modifications to increase the active binding sites and also made them readily available for sorption. Huang and Huang stated that pre-treatment of biomass removes the surface impurities on the biosorbents and expose the available binding sites for metal sorption.(5)

\section{TOXIC EFFECTS OF CHROMIUM}

Chromium was discovered in 1797 by Vauqelin. Numerous industrial application raised chromium to very important economic element. At the same time with the development of its uses the adverse effect of chromium compounds in human health were being defined. Chromium has pure metal has no adverse effect. Little toxic effect is attributed to trivalent chromium when present in large quantities. Both acute and chronic toxicity of chromium are mainly caused by hexavalent compounds. Several in vitro studies indicated that high concentrations of chromium(III) in the cell can lead to DNA damage.

Hexavalent chromium is also one of the substances whose use is restricted by the European Restriction of Hazardous Substance Directive. The carcinogenity of chromate dust has been known for a long time, and 1890 the first publication described the elevated cancer risk of workers in a chromate dye company. Three mechanisms have been proposed to describe the genotoxicity of chromium (VI) to chromium(III). The first mechanism includes highly reactive hydroxyl radicals and other reactive radicals which are by products of the direct binding chromium(VI), produced by reduction in the cell to the 
DNA. The last mechanism attributes the genotoxicity to the binding to the DNA of the end product of the chromium(III) reduction. Overexposure to chromium can occur in welders and other workers in the metallurgical industry, persons taking chromium-containing dietary supplements ,patients who have received metallic surgical implants and individuals who ingest chromium salts. Chromium concentrations in whole blood ,plasma, serum or urine may be measured to monitor assist in the forensic investigation in the case of fatal over dosage. Since plants lack a specific transport system for $\mathrm{Cr}$, it is taken up by carriers of essential ions such as sulfate or iron. Toxic effects of $\mathrm{Cr}$ on plant growth and development include alterations in the germination process as well as in thegrowth of roots, stems and leaves, which may affect total dry matter production and yield. Cr also causes deleterious effects on plant physiological processes such as photosynthesis, water relations and mineral nutrition. Metabolic alterations by $\mathrm{Cr}$ exposure have also been described in plants either by a direct effect on enzymes or other metabolites or by its ability to generate reactive oxygen species which may cause oxidative for safety in exposed workers, to confirm the diagnosis in potential poisoning victims, or to stress. The potential of plants with the capacity to accumulate or to stabilize $\mathrm{Cr}$ compounds for bioremediation of $\mathrm{Cr}$ contamination has gained interest in recent years.(3)

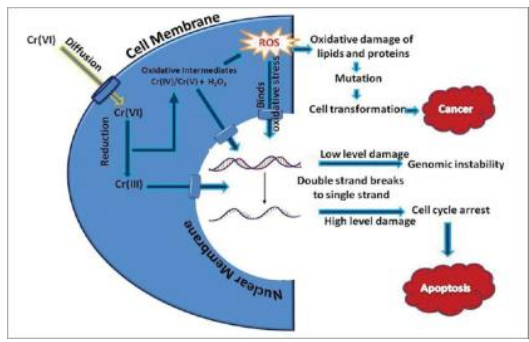

Figure 1. Effect of chromium in animal cell

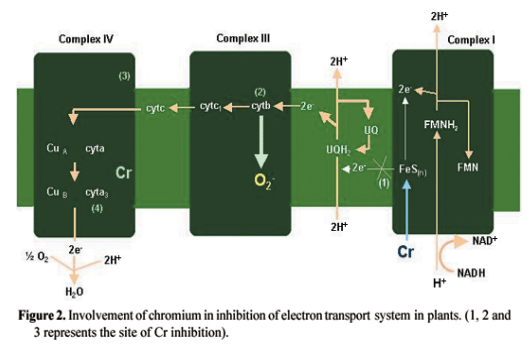

ADSORPTION

Adsorption refers to the existence of a higher concentration of a molecular species at the surface of solid or liquid material than is present in the bulk of the material. The material attracts and retains other species on its surface is called the adsorbent and the species that gets retained on the surface of material is called adsorbate. ie ,the adsorbing material is called adsorbent and the material that gets adsorbed is called adsorbate. The process in which an adsorbed material leaves the surface is called desorption.

Adsorption is different from absorption. In absorption, the molecules of a substance are uniformly distributed in the bulk of other, whereas in adsorption molecule of one substances are present in higher concentration at the surface rather than bulk of the other substances.

\section{ADSORPTION ISOTHERMS}

The process of Adsorption is usually studied through graphs know as adsorption isotherm. It is the graph between the amounts of adsorbate $(\mathrm{x})$ adsorbed on the surface of adsorbent (m) and pressure at constant temperature. Different adsorption isotherms have been Freundlich, Langmuir and BET theory.

\section{a) Basic Adsorption Isotherm}

In the process of adsorption, adsorbate gets adsorbed on adsorbent.

$$
\begin{aligned}
& \text { Adsorbate }+ \text { Adsorbent } \stackrel{\text { Adsorption }}{\rightleftharpoons} \text { Adsorption } \\
& \text { desorption }
\end{aligned}
$$

\section{$\mathrm{A}+\mathrm{B} \rightleftharpoons \mathrm{AB}$}

According to Le- Chatelier principle, the direction of equilibrium would shift in that direction where the stress can be relieved. In case of application of excess of pressure to the equilibrium system, the equilibrium will shift in the direction where the number of molecules decreases. Since number of molecules decreases in forward direction, with the increases in pressure, forward direction of equilibrium will be favored.

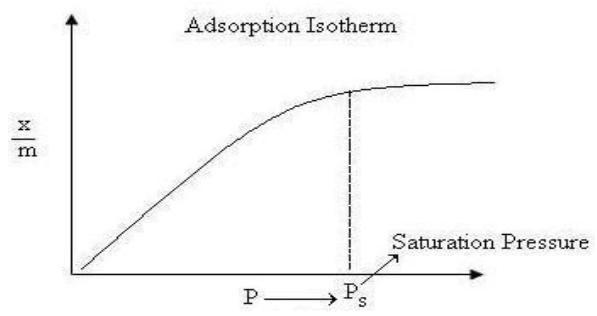

Fig.3.Basic Adsorption Isotherm

From the graph, we can predict that after saturation pressure Ps, adsorption does not occur anymore. This can be explained by the fact that there are limited numbers of vacancies on the surface of the adsorbent. At high pressure a stage is reached when all the sites are occupied and further increase in pressure does not cause any difference in adsorption process. At high pressure, Adsorption is independent of pressure.

\section{b) Freundlich Adsorption Isotherm}

In 1909, Freundlich gave an empirical expression representing the isothermal variation of adsorption of a quantity of gas adsorbed by unit mass of solid adsorbent with pressure. This equation is known as Freundlich Adsorption Isotherm or Freundlich Adsorption equation or simply Freundlich Isotherm.

$$
\frac{x}{m}=k P^{\frac{1}{n}}
$$

Where $\mathrm{x}$ is the mass of the gas adsorbed on mass $\mathrm{m}$ of the adsorbent at pressure $\mathrm{p}$ and $\mathrm{k}, \mathrm{n}$ are constants whose values 
depend upon adsorbent and gas at particular temperature. Though Freundlich Isotherm correctly established the relationship of adsorption with pressure at lower values, it failed to predict value of adsorption at higher pressure.

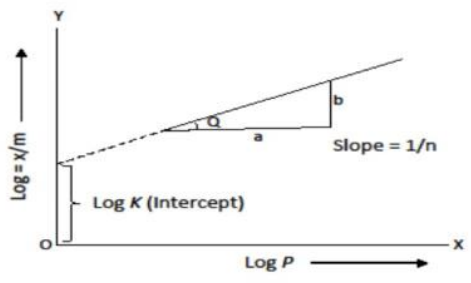

\section{c) Langmuir Adsorption Isotherm}

In 1916 Langmuir proposed another Adsorption Isotherm known as Langmuir Adsorption isotherm. This isotherm was based on different assumptions one of which is that dynamic equilibrium exists between adsorbed gaseous molecules and the free gaseous molecules.

$$
\mathrm{A}(\mathrm{g})+\mathrm{B}(\mathrm{S}) \underset{\text { desorption }}{\stackrel{\text { Adsorption }}{\rightleftharpoons}} \mathrm{AB}
$$

Where $\mathrm{A}(\mathrm{g})$ is unadsorbed gaseous molecule, $\mathrm{B}(\mathrm{s})$ is unoccupied metal surface and $\mathrm{AB}$

Adsorbed gaseous molecule.Based on his theory, he derived Langmuir Equation which depicted a relationship between the number of active sites of the surface undergoing adsorption and pressure.

$$
\theta=\frac{K P}{1+K P}
$$

Where $\theta$ the number of sites of the surface which are covered with gaseous molecule, $\mathrm{P}$ represents pressure and $\mathrm{K}$ is the equilibrium constant for distribution of adsorbate between the surface and the gas phase .The basic limitation of Langmuir adsorption equation is that it is valid at low pressure only. At lower pressure, KP is so small, that factor $(1+\mathrm{KP})$ in denominator can almost be ignored. So Langmuir equation reduces to

$$
\theta=\mathrm{KP}
$$

At high pressure $\mathrm{KP}$ is so large, that factor $(1+\mathrm{KP})$ in denominator is nearly equal to KP. So Langmuir equation reduces to

$$
\theta=\frac{K P}{K P}=1
$$

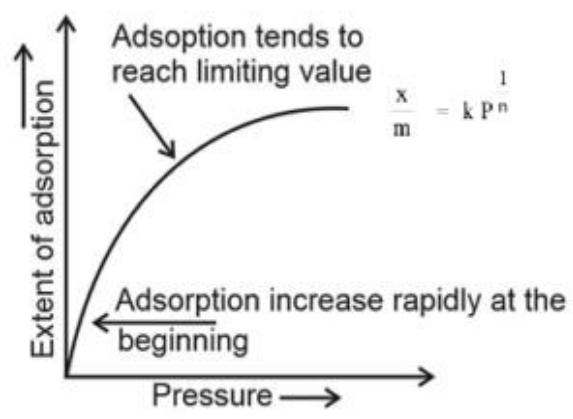

Fig.5. Langmuir adsorption isotherm

\section{TAMARIND FRUIT SHELL}

Tamarind( tamarind indica) consist of fruit, black seeds and husk. Tamarind husk is outer shell of tamarind fruit obtained after removing the fruit the process for obtaining tamarind husk is during the separation process to remove the fruit and the black seed. Tamarind seed husk is brown outer shell of black seed obtained after decortications of roasted seeds. It has wide uses in fuel and cattle feed industry and also tannins extracted from tamarind husk are used in leather industry and tamarind husk is also used for fish poison. Tamarind indica fruit shells (TIFSs) are naturally calcium rich compounds. They were impregnated with ammonium carbonate and then carbonized, leading to ammonium carbonate activated ACA-TIFS carbon. The resulting materials and carbon arising from virgin fruit shells V-TIFS were characterized and assayed as adsorbent for the removal of fluoride anions from groundwater. Tamarind husk and seed husk uses are not limited to know applications and usages but it has many unknown usages and applications.(2)

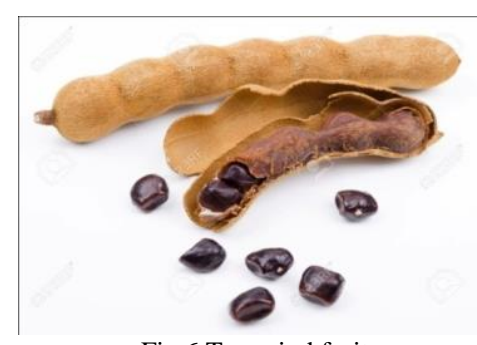

Fig.6.Tamarind fruit

\section{Materials used}

Tamarind fruit shell (waste product of tamarind pulp were collected from the natural tamarind trees), $\mathrm{HCl}, \mathrm{NaOH}$, $\mathrm{K}_{2} \mathrm{Cr}_{2} \mathrm{O}_{7}$, Mohr's salt, $2 \mathrm{~N} \mathrm{H}_{2} \mathrm{SO}_{4}$ etc.

\section{Methods used}

\section{a) Preparation of Crude Tamarind Fruit Shell (CTFS) biosorbent}

Tamarind fruit shells, a waste product of tamarind pulp were collected from the natural tamarind trees. The tamarind fruit shells are cleaned with distilled water, and are powdered and sieved to get uniform size. They are again washed thoroughly with distilled water and dried in the oven for 2 hours at $60^{\circ} \mathrm{C}$. It is used as a biosorbent called Crude Tamarind Fruit shell (CTFS).

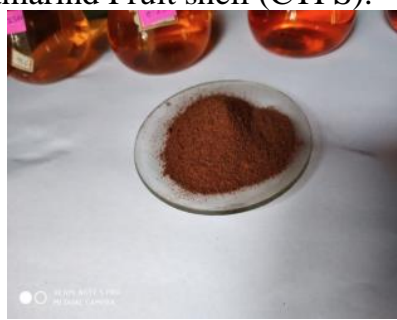

Fig.7.CTFS sample

b) Pre-treatment of the biosorbent

The pre-treatment of tamarind shells is carried out to increase the metal uptake efficiency. $10 \mathrm{~g}$ of the tamarind shells are treated with $100 \mathrm{ml} 1 \mathrm{~N} \mathrm{HCl}$ for $24 \mathrm{hrs}$ separately 
and kept on the water bath $\left(70^{\circ} \mathrm{C}\right)$ for half an hour. It is cooled and is neutralized with $50 \mathrm{ml}$ of $1 \mathrm{~N} \mathrm{NaOH}$. The filtrates are separated and are dried in the oven for $4 \mathrm{hrs}$ at $60^{\circ} \mathrm{C}$. Thus the pretreated tamarind fruit shells H-TS, is used as a second and third biosorbent.

\section{c) Effect of $\mathbf{p H}$}

The effect of $\mathrm{pH}$ on chromium biosorption on CTFS and H-TS are studied at room temperature by varying $\mathrm{pH}$ of chromium solution. The $\mathrm{pH}$ of the solutions is adjusted with $0.05 \mathrm{~N} \mathrm{HCl}$ and $0.05 \mathrm{~N} \mathrm{NaOH}$ by making use of digital $\mathrm{pH}$ meter.

\section{d) Preparation of potassium dichromate solution}

1N Potassium dichromate was prepared by weighing accurately $12.25 \mathrm{~g}$ of potassium dichromate in a $250 \mathrm{ml}$ standard flask, dissolved in distilled water and made up to the mark, shaken well for uniform concentration. From the stock solution different concentrations like $0.5 \mathrm{~N}$, $0.25 \mathrm{~N}$ and $0.125 \mathrm{~N}$ was prepared by pipetting $50 \mathrm{ml}$, $25 \mathrm{ml}$ and $12.25 \mathrm{ml}$ in $100 \mathrm{ml}$ standard flask and made up to the mark, shaken well for uniform concentration.

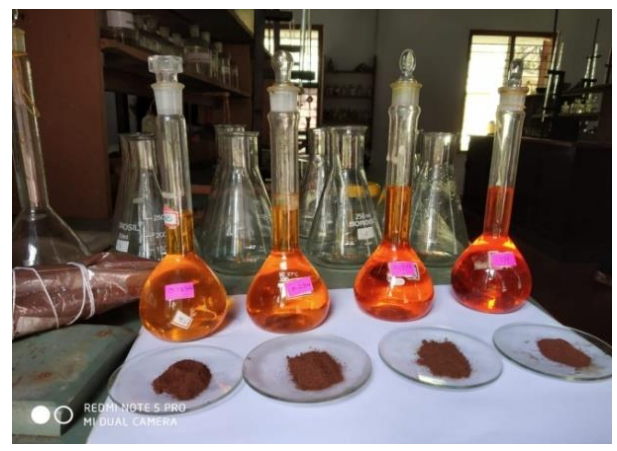

Fig.8.potassium dichromate solution

\section{e) Batch studies}

$\mathrm{pH}$ of the potassium dichromate solution is adjusted with $0.05 \mathrm{~N} \mathrm{HCl}$ and $0.05 \mathrm{~N} \mathrm{NaOH}$. For the first set of solution $\mathbf{p H}$ is adjusted to 3 and for the second set of solution $\mathbf{p H}$ were adjusted to 5. Batch adsorption experiments are carried out by shaking $1 \mathrm{~g}$ of biosorbent mixed with $50 \mathrm{ml}$ potassium dichromate solution of known concentration in each flask solution. Then flasks where shaken thoroughly for about an hour and then kept in a trey containing water to reach equilibrium. After 12 hours the mixture was filtered using whatmann filter paper no.1.

The experiment is repeated with both CTFS and H-TS

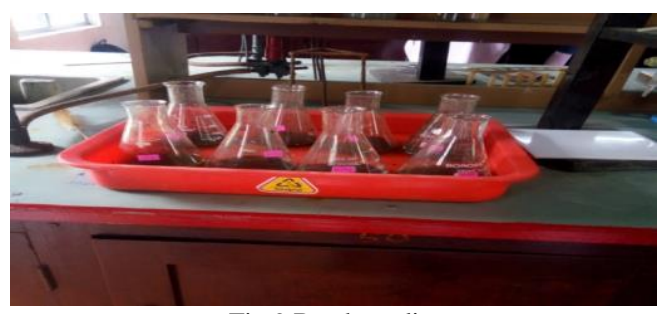

Fig.9.Batch studies

\section{f) Preparation of $0.1 \mathrm{~N}$ Mohr's salt solution}

About $9.8 \mathrm{~g}$ Mohr's salt was accurately weighed into $250 \mathrm{ml}$ standard flask and made up to the mark, shaken well for uniform concentration.

\section{g)Titration of the test sample}

$10 \mathrm{ml}$ of Mohr's salt and $20 \mathrm{ml}$ of $2 \mathrm{~N}$ sulphuric acid was pipetted out into a conical flask. 10 drops of N-Phenyl anthranilic acid was added as an indicator and titrated against potassium dichromate from burette. At the end point the green

Colour changed into wine red colour. Experiment is repeated for all known concentration and $\mathrm{pH}$ of potassium dichromate solution.

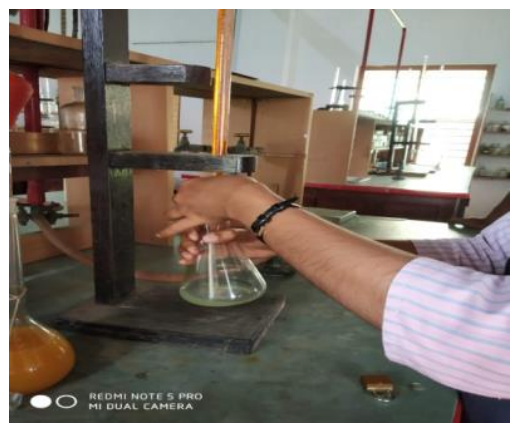

Fig.10 sample before titration

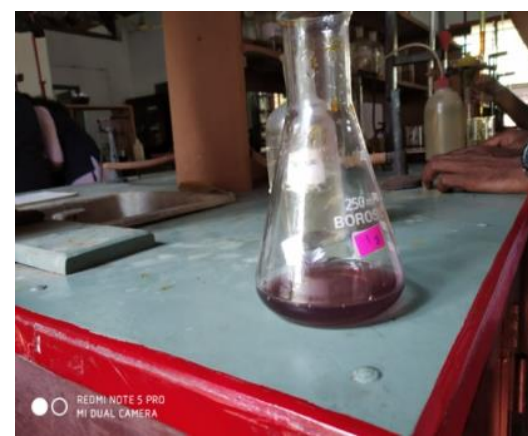

Fig11. Sample after titration

RESULT AND DISCUSSIONS

PERCENTAGE OF REMOVAL WITH INITIAL CONCENTRATION

a) Percentage of removal of chromium with initial concentration using CTFS at $\mathrm{p} \mathbf{H}=3$

\begin{tabular}{|c|c|c|c|c|c|}
\hline $\begin{array}{c}\text { Sl } \\
\text { no. }\end{array}$ & $\begin{array}{c}\text { Initial } \\
\text { concentration } \\
\left(C_{o}\right)\end{array}$ & $\begin{array}{c}\text { Vol. of } \\
\text { Mohr's } \\
\text { salt }\end{array}$ & $\begin{array}{c}\text { Vol. of } \\
\mathbf{K}_{\mathbf{2}} \mathbf{C r}_{2} \mathbf{O}_{7}\end{array}$ & $\begin{array}{c}\mathbf{C o n . ~ O f} \\
\mathbf{K}_{\mathbf{2}} \mathbf{C r}_{2} \mathbf{O}_{7} \\
\left(C_{e}\right)\end{array}$ & $\begin{array}{c}\text { \% of } \\
\text { removal of } \\
\text { Chromium }\end{array}$ \\
\hline 1. & 1.00 & 10 & 1.6 & 0.625 & $37.5 \%$ \\
\hline 2. & 0.50 & 10 & 3.2 & 0.3125 & $37.5 \%$ \\
\hline 3. & 0.25 & 10 & 10.2 & 0.098 & $60.8 \%$ \\
\hline 4. & 0.125 & 10 & 25 & 0.040 & 68 \\
\hline
\end{tabular}

$C_{e}=(\mathbf{0 . 1} *$ Vol. of Mohr's salt $) /$ Vol.of $\mathrm{K}_{2} \mathrm{Cr}_{2} \mathrm{O}_{7}$

$\%$ of removal $=\left(\left(C_{o}-C_{e}\right) / C_{o}\right) * 100$ 


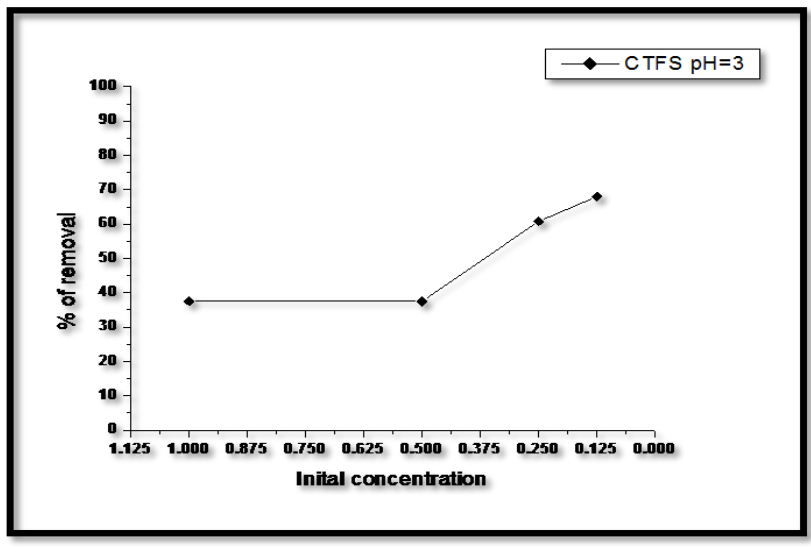

b) Percentage of removal of chromium with initial concentration using CTFS at $\mathbf{p} \mathbf{H}=5$

\begin{tabular}{|c|c|c|c|c|c|}
\hline $\begin{array}{c}\text { S1 } \\
\text { no. }\end{array}$ & $\begin{array}{c}\text { Initial } \\
\text { concentration }\left(C_{o}\right. \\
)\end{array}$ & $\begin{array}{c}\text { Vol. of } \\
\text { Mohr's } \\
\text { salt }\end{array}$ & $\begin{array}{c}\text { Vol. of } \\
\mathrm{K}_{2} \mathrm{Cr}_{2} \mathrm{O}_{7}\end{array}$ & $\begin{array}{c}\mathrm{Con.} \mathrm{Of} \\
\mathrm{K}_{2} \mathrm{Cr}_{2} \mathrm{O}_{7} \\
\left(C_{e}\right)\end{array}$ & $\begin{array}{c}\% \text { of } \\
\text { remova } \\
1 \text { of } \\
\text { Chromi } \\
\text { um }\end{array}$ \\
\hline 1. & 1.00 & 10 & 1.4 & 0.714 & $28.6 \%$ \\
\hline 2. & 0.50 & 10 & 3 & 0.333 & $34 \%$ \\
\hline 3. & 0.25 & 10 & 8 & 0.125 & $50 \%$ \\
\hline 4. & 0.125 & 10 & 19 & 0.052 & $58.4 \%$ \\
\hline
\end{tabular}

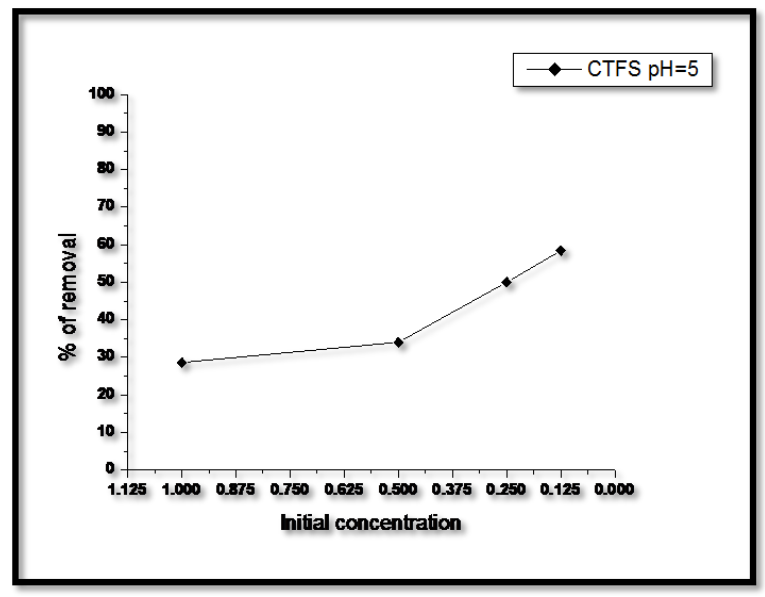

c) Percentage of removal of chromium with initial concentration using $\mathrm{H}$-TS at $\mathbf{p} \mathrm{H}=\mathbf{3}$

\begin{tabular}{|c|c|c|c|c|c|}
\hline $\begin{array}{l}\text { Sl } \\
\text { no. }\end{array}$ & $\begin{array}{c}\text { Initial } \\
\text { concentration } \\
\left(\boldsymbol{C}_{\boldsymbol{o}}\right)\end{array}$ & $\begin{array}{l}\text { Vol. } \\
\text { of } \\
\text { Mohr } \\
\text { 's salt }\end{array}$ & $\begin{array}{c}\mathrm{Vol} \text {. of } \\
\mathrm{K}_{2} \mathrm{Cr}_{2} \mathrm{O}_{7}\end{array}$ & $\begin{array}{c}\text { Con. Of } \\
\mathrm{K}_{2} \mathrm{Cr}_{2} \mathrm{O} \\
7\left(\boldsymbol{C}_{\boldsymbol{e}}\right)\end{array}$ & $\begin{array}{l}\% \text { of } \\
\text { remov } \\
\text { al of } \\
\text { Chro } \\
\text { mium }\end{array}$ \\
\hline 1. & 1.00 & 10 & 1.9 & 0.526 & $47.4 \%$ \\
\hline 2. & 0.50 & 10 & 4.8 & 0.208 & $58.4 \%$ \\
\hline 3. & 0.25 & 10 & 11.2 & 0.089 & $\begin{array}{c}64.32 \\
\%\end{array}$ \\
\hline 4. & 0.125 & 10 & 34 & 0.029 & $\begin{array}{c}76.48 \\
\%\end{array}$ \\
\hline
\end{tabular}

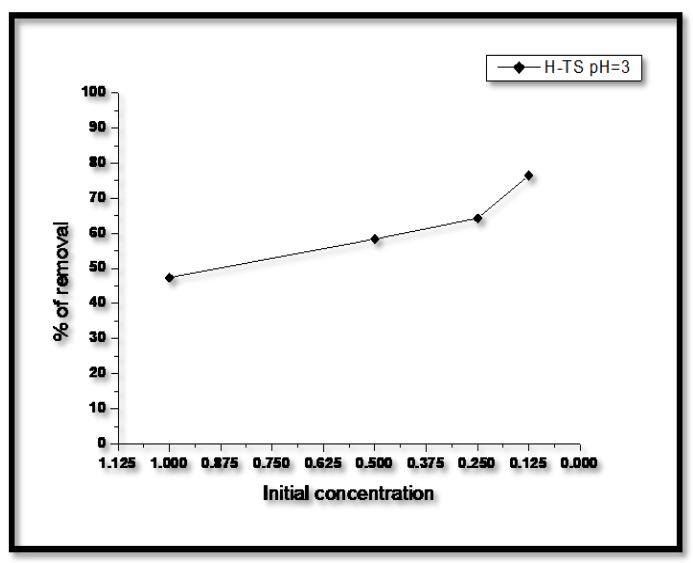

d) Percentage of removal of chromium with initial concentration using $H$-TS at $\mathbf{p H}=$

\begin{tabular}{|c|c|c|c|c|c|}
\hline $\begin{array}{c}\text { Sl } \\
\text { no } \\
\cdot\end{array}$ & $\begin{array}{c}\text { Initial } \\
\text { concentration } \\
\left(\boldsymbol{C}_{\boldsymbol{o}}\right)\end{array}$ & $\begin{array}{c}\text { Vol. of } \\
\mathbf{M o h r} \\
\mathbf{s} \text { salt }\end{array}$ & $\begin{array}{c}\text { Vol. of } \\
\mathbf{K}_{2} \mathbf{C r}_{2} \mathbf{O}_{7}\end{array}$ & $\begin{array}{c}\mathbf{C o n . ~ O f} \\
\mathbf{K}_{2} \mathbf{C r}_{2} \mathbf{O} \\
7\left(\boldsymbol{C}_{\boldsymbol{e}}\right)\end{array}$ & $\begin{array}{c}\text { \% of } \\
\text { removal } \\
\text { of } \\
\text { Chromi } \\
\mathbf{u m}\end{array}$ \\
\hline 1. & 1 & 10 & 1.6 & 0.625 & $37.5 \%$ \\
\hline 2. & 0.50 & 10 & 3.2 & 0.312 & $37.5 \%$ \\
\hline 3. & 0.25 & 10 & 9.8 & 0.1020 & $59.2 \%$ \\
\hline 4. & 0.125 & 10 & 30 & 0.0333 & $73.6 \%$ \\
\hline
\end{tabular}

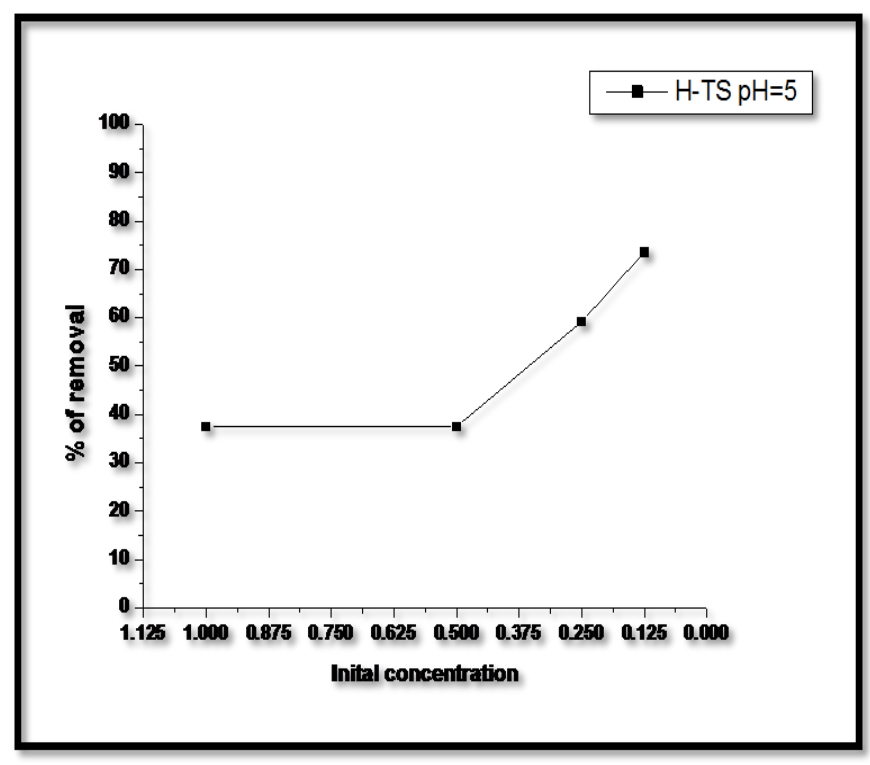

EFFECT OF CTFS AND H-TS

The removal of $\mathrm{Cr}(\mathrm{VI})$ is maximum for pretreated biosobent (H-TS).ie the adsorptive capacities of the pretreated form are greater than crude form. The treatment of biomass with $\mathrm{HCl}$ implies the protonation which displace the lighter metal ions from binding sites.(i.e, carboxylic, sulphonic etc. ). Acid treatment results not only in clean up 
of the surface impurities, stabilization of the surface compounds, and increasing the surface area by opening the available sites for metal adsorption.

\section{EFFECT OF INITIAL CONCENTRATION}

Removal of chromium decreases with increase in the initial concentration. We can see that maximum removal of chromium takes place at a lower concentration of $0.125 \mathrm{~N}$ at all $\mathrm{p} \mathrm{H}$.

\section{EFFECT OF p H}

Solution $\mathrm{p} \mathrm{H}$ can significantly influence the removal of heavy metals, here we use two different $\mathrm{p} \mathrm{H}$ conditions and study the rate of adsorption, it is found that adsorption is maximum at low $\mathrm{p} \mathrm{H}$.The decrease in adsorption with increase in $\mathrm{p} \mathrm{H}$ may be due to the decrease in electrostatic force of attraction between the sorbent and sorbate ions. At lower $\mathrm{p} \mathrm{H}$, due to high electrostatic force of attraction, the percentage of $\mathrm{Cr}(\mathrm{VI})$ removal is high. At very low $\mathrm{p} \mathrm{H}$, the surface of the sorbent is surrounded by hydronium ion which enhances the adsorption of hexavalent chromium.

\section{GENERATIONFOF DATA FOR FREUNDLICH ADSORPTION ISOTHERM \\ a) CTFS p H $=3$}

\begin{tabular}{|c|c|c|c|c|c|}
\hline $\begin{array}{c}\text { Mass of } \\
\text { adsorbent } \\
\mathrm{m}\end{array}$ & $\begin{array}{c}\mathrm{X}=C_{o} \\
-C_{e}\end{array}$ & $\mathrm{x} / \mathrm{m}$ & $\log C_{e}$ & $\log \mathrm{x} / \mathrm{m}$ & $\begin{array}{c}C_{e} \\
/(\mathrm{x} / \mathrm{m})\end{array}$ \\
\hline 1 & 0.375 & 0.375 & -0.204 & -0.4259 & 1.666 \\
\hline 1 & 0.1875 & 0.1875 & -0.5051 & -0.7269 & 1.666 \\
\hline 1 & 0.152 & 0.152 & -1.0087 & -0.8181 & 0.664 \\
\hline 1 & 0.085 & 0.085 & -1.397 & -1.0705 & 0.4705 \\
\hline
\end{tabular}

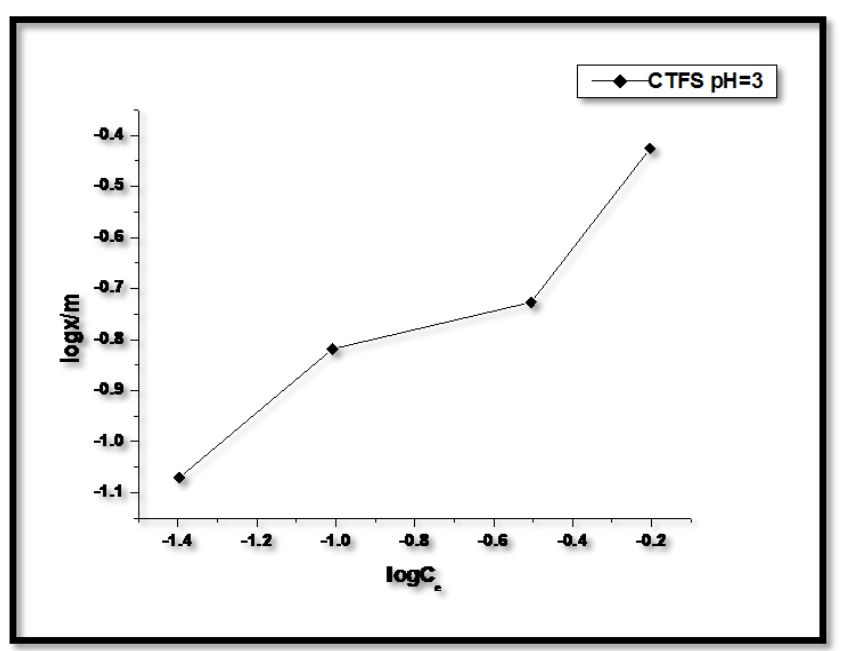

b) CTFS p $\mathbf{H}=\mathbf{5}$

\begin{tabular}{|c|c|c|c|c|c|}
\hline $\begin{array}{c}\text { Mass of } \\
\text { adsorbent } \\
\mathrm{m}\end{array}$ & $\begin{array}{c}\mathrm{X}= \\
C_{o}- \\
C_{e}\end{array}$ & $\mathrm{x} / \mathrm{m}$ & $\log C_{e}$ & $\begin{array}{c}\log \\
\mathrm{x} / \mathrm{m}\end{array}$ & $\begin{array}{c}C_{e} \\
/(\mathrm{x} / \mathrm{m})\end{array}$ \\
\hline $\mathbf{1}$ & 0.286 & 0.286 & -0.146 & $\begin{array}{c}- \\
0.5436\end{array}$ & 2.496 \\
\hline $\mathbf{1}$ & 0.167 & 0.167 & -0.477 & $\begin{array}{c}- \\
0.7772\end{array}$ & 1.9940 \\
\hline $\mathbf{1}$ & 0.125 & 0.125 & $\begin{array}{c}- \\
-\end{array}$ & 1 \\
\hline $\mathbf{1}$ & 0.073 & 0.073 & 1.2839 & $\begin{array}{c}- \\
1.1366\end{array}$ & 0.7123 \\
\hline
\end{tabular}

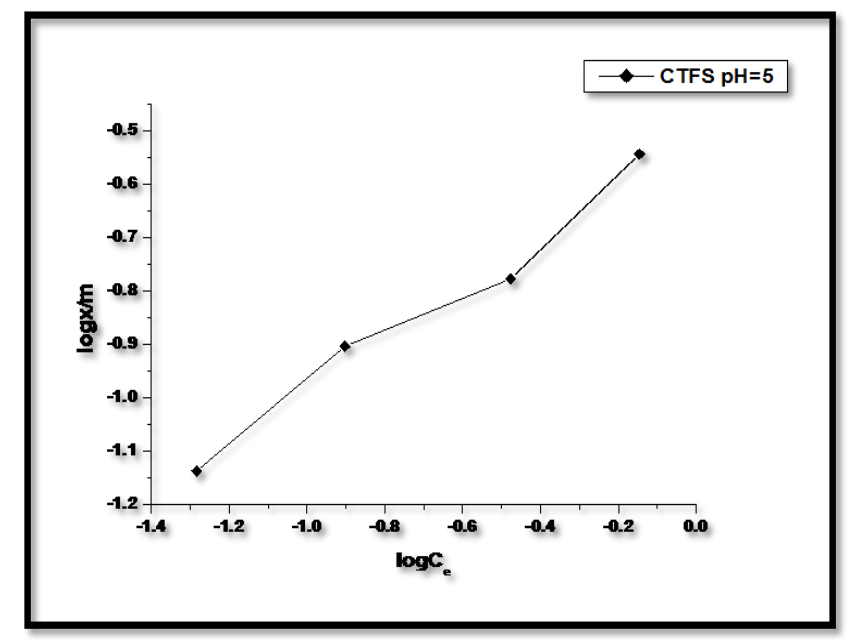

c) H-TS p $\mathbf{H}=\mathbf{3}$

\begin{tabular}{|c|c|c|c|c|c|}
\hline $\begin{array}{c}\text { Mass of } \\
\text { adsorbent } \\
\mathrm{m}\end{array}$ & $\begin{array}{c}\mathrm{X}= \\
C_{o}- \\
C_{e}\end{array}$ & $\mathrm{x} / \mathrm{m}$ & $\begin{array}{c}\log \\
C_{e}\end{array}$ & $\begin{array}{c}\log \\
\mathrm{x} / \mathrm{m}\end{array}$ & $\begin{array}{c}C_{e} \\
/(\mathrm{x} / \mathrm{m})\end{array}$ \\
\hline $\mathbf{1}$ & 0.474 & 0.474 & $\begin{array}{c}- \\
0.279\end{array}$ & $\begin{array}{c}- \\
0.3242\end{array}$ & 1.1097 \\
\hline $\mathbf{1}$ & 0.292 & 0.292 & $\begin{array}{c}- \\
0.682\end{array}$ & $\begin{array}{c}- \\
0.5346\end{array}$ & 0.7123 \\
\hline $\mathbf{1}$ & 0.1608 & 0.1608 & $\begin{array}{c}- \\
1.049\end{array}$ & $\begin{array}{c}- \\
0.7937\end{array}$ & 0.5534 \\
\hline $\mathbf{1}$ & 0.0956 & 0.0956 & $\begin{array}{c}- \\
1.531\end{array}$ & $\begin{array}{c}- \\
1.0195\end{array}$ & 0.3033 \\
\hline
\end{tabular}




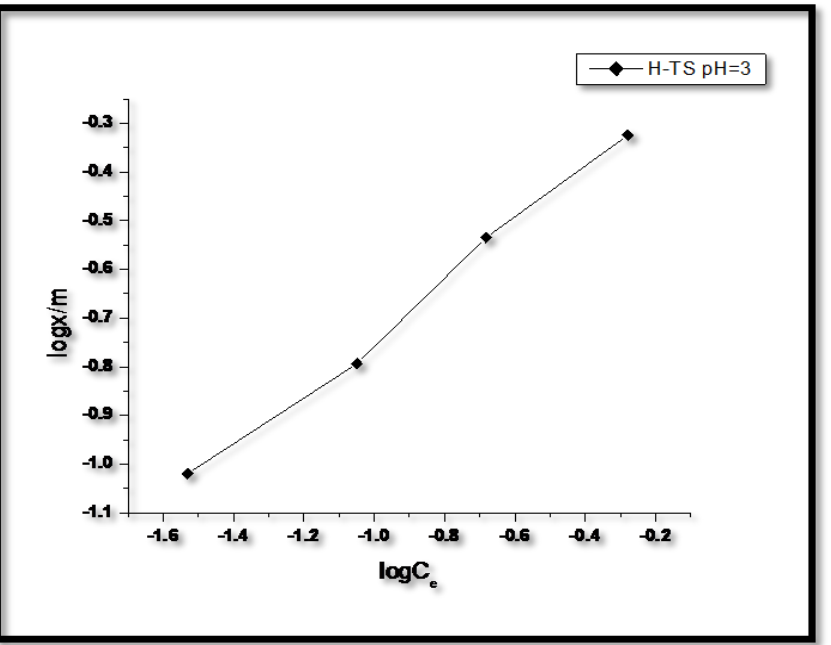

d) H-TS p H $=5$

\begin{tabular}{|c|c|c|c|c|c|}
\hline $\begin{array}{c}\text { Mass of } \\
\text { adsorbent } \\
\mathbf{m}\end{array}$ & $\begin{array}{c}\mathbf{X}= \\
\boldsymbol{C}_{\boldsymbol{o}}- \\
\boldsymbol{C}_{\boldsymbol{e}}\end{array}$ & $\mathbf{x} / \mathbf{m}$ & $\log \boldsymbol{C}_{\boldsymbol{e}}$ & $\begin{array}{c}\log \\
\mathbf{x} / \mathbf{m}\end{array}$ & $\begin{array}{c}\boldsymbol{C}_{\boldsymbol{e}} \\
/(\mathbf{x} / \mathbf{m})\end{array}$ \\
\hline $\mathbf{1}$ & 0.375 & 0.375 & $\begin{array}{c}- \\
0.2041\end{array}$ & $\begin{array}{c}- \\
0.4259\end{array}$ & 1.666 \\
\hline $\mathbf{1}$ & 0.1875 & 0.1875 & - & - & 1.664 \\
\hline $\mathbf{1}$ & 0.148 & 0.148 & -0.991 & - & 0.689 \\
\hline $\mathbf{1}$ & 0.092 & 0.092 & -1.481 & - & 0.3619 \\
\hline
\end{tabular}

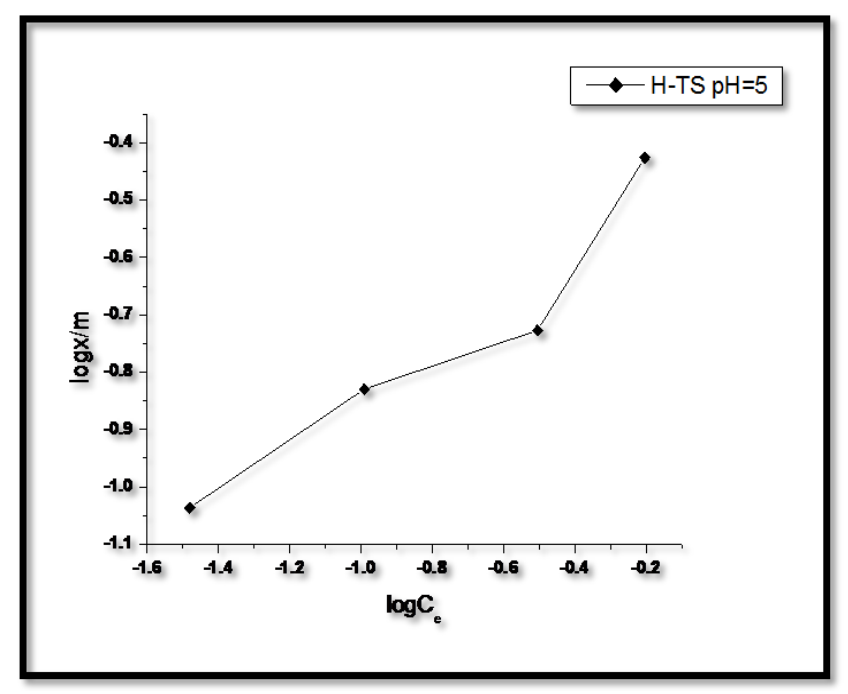

The graph $\log C_{e}$ Vs $\log x / m$ is a straight line from that we conclude that the adsorption of chromium using tamarind fruit shell follows the Freundlich adsorption isotherm.

The data is also fit well to Langmuir adsorption isotherm.

\section{CONCLUSIONS}

- Biosorbents CTFS and H-TS have maximum adsorption capacity compared to many adsorbents.

- $\quad$ The tamarind fruit shell both it's natural and acid treated forms are excellent biosorbents for the removal of chromium ions.

- $\quad$ The $\%$ of removal of chromium is reduced with increase in initial metal ion concentration.

- The maximum $\%$ of removal chromium occurred at $0.125 \mathrm{~N}$.

- The maximum uptake of Chromium (VI) ions occurs at $\mathrm{p} \mathrm{H}=3$.

- $\quad$ The data fits well to both Langmuir and Freundlich isotherms.

\section{REFERENCE}

[1] RICOU-HOEFER, LECUYER, I and LE CLOIREC, P.Experimental design methodology applied to adsorption of metallic ions onto fly ash. Water Research, March 2001, vol. 35, no. 4 ,p. 965 .

[2] ROUQUEROL, J, AVNIR, D FAIRBRIDGE. C, EVERETT , D.H ; HAYNES,

[3] i J.H. PERNICONE, N. RAMSAY, J.D.F. SING, K.S.W. and UNGER ,K.K Recommendations for the characterization of porous solids. Pureand Applied chemistry , August 1994, vol. 66, no. 8 , p. $1739-1758$

[4] SHARMA, D.C and FORESTER , C.F . A preliminary examination into the adsorption of hexavalent chromium using low -cost adsorbents. Bioresources Technology , 1994, vol.47, no.3 ,p.257-264

[5] SHEKNAAH, P; KADIRVELU, K; KANMANI , P. SENTHILKUMAR, P and SUBBURAM , V. Adsorption of lead (II) from aqueous solution by activated carbon prepared from Eichhornia . Journal of Chemical Technology and Biotechnology , April 2002, vol.77, no.4, p.458-464

[6] G. Rich, K. Cherry, Hazardous Waste Treatment Technologies, Pudvan Publishers, New york (1987)

[7] AGARWAL, G.S.; BHUPTAWAT, H.K. and CHAUDHARI, S. Biosorption of aqueous $\mathrm{Cr}(\mathrm{VI})$ by Tamarindus indica seeds. Bioresource Technology, May 2006, vol. 97, no. 7, p. 949-956

[8] LVES, M.M.; GONZÁLEZ BEÇA, C.G.; GUEDES DE CARVALHO, R.; CASTANHEIRA, J.M.; SOL PEREIRA, M.C.; and VASCONCELOS, L.A.T. Chromium removal in tannery wastewaters "polishing" by Pinus sylvestris bark. Water Research, August 1993, vol. 27, no. 8, p. 1333-1338. 